\title{
Impactul managementului disfagiei asupra calității vieții persoanelor cu accident vascular cerebral
}

\author{
Raluca-Mariana POPA ${ }^{1}$
}

\begin{abstract}
The objective of the following research is the investigation of the impact that management of dysphagia has upon quality of life in persons with neurological pathology of vascular cerebreal attack type. The group of participants in this study has 6 members with ages between 34 and 69, all suffering from a neurological pathology of VCA type or cranio-cerebreal trauma with direct implications on the swallowing process. This paper used case study methode as experimental design, the goal being to detect the impact that speach therapy has on the dysphagia, in the context of safety and quality of life. A series of instruments regarding clinical evaluation of dysphagia and quality of life in the context of VCA and dysphagia where been translated and adapted in the fallowing research.
\end{abstract}

Keywords: dysphagia, life quality, celebral stroke, speech language therapy

\section{Introducere}

Cercetarea de față și-a propus sondarea impactului managementului disfagiei asupra calității vieții persoanelor cu accidente vasculare cerebrale. Această cercetare a fost realizată pe un microeșantion de șase subiecți aplincându-se o varietate de teste ce sondează gradul disfagiei și impactul terapiei logopedice asupra calității vieții. Evaluarea acestui impact a fost surprins $\mathrm{cu}$ ajutorul următoarelor teste: Stroke Specific Quality of life Scale (SS-QOL); Barthel Index; Swalloing Quality of Life Questionnaire (SWAL-QOL); Water swallow test; Modified Wather swallow test; Instrument de evaluare a deglutiției (IED-10); Instrument de evaluare clinică a deglutiției; Disphagia handicap Index (DHI); Fork Drip test; Fork Pressure Test and Spoon Pressure Test. Pacienții care au suferit un accident vascular cerebral, ce sau sondat $\mathrm{cu}$ patologii motorii asociate $\mathrm{cu}$ tulburări de deglutiție, impactul resimțit de persoană este mult mai mare, adesea acesta experimentând teamă de a mânca, de a înghiții, anxietate mărită pe tot parcursul alimentării și al hidratării, uneori mergând până la refuzul complet de alimente și depresie. Nu trebuie să uităm și de aspectul social și de interacțiune pe care îl exercită rutina mesei. Prin urmare demersul terapeutic și de reabilitare trebuie să țină seama de dorința de alimentație, durata alimentației, frecvența simptomelor, funcția socială, selecția alimentelor, comunicarea, frica, sănătatea mentală, nevoia de somn și oboseală (Ayres, A și colab., 2016).

Deglutiția sau înghițirea este acel proces mecanic voluntar și reflex în care sunt implicate peste 50 de nervi și mușchi, prin care alimentele sunt împinse de la nivelul cavității bucale, în faringe, apoi în esofag având drept destinație finală stomacul (Jones, B.,2003.) Prin urmare înghițirea cuprinde totalitatea activităților motorii ce asigură transportul bolului alimentar din cavitatea bucală în stomac, proces ce 
constă într-un lanț de mișcări voluntare și reflexe. În strânsă legătură cu structura anatomică care este implicată în actul deglutițional cercetătorii vorbesc și clasifică, în literatura de specialitate, deglutiția în trei faze principale: faza orală, faza faringiană și faza esofagiană. Orice perturbare ce poate surveni în desfășurarea acestui proces, fie că este vorba de faza orală, faringiană sau esofagiană a deglutiției, determină dificultăți în înghițire, regăsite în literatura de specialitate sub denumirea de disfagie, cu un impact mai mic sau mai mare asupra sănătății individului.

Conform cercetărilor efectuate de Bhattacharyya în 2014 se arată că la nivelul USA unul din 25 de adulți se confruntă cu tulburări de înghițire. Studiile epidemiologice indică faptul că disfagia are o prevelență mai ridicată în cadrul vârsnicilor (Cabré, M. și colab., 2014). Chiar dacă există mai multe grade de dificultate a disfagiei, statisticile de sănătate publică din Regatul Unit, declară în 2011 că aproximativ 11\% din populația acesteia este afectată de disfagie. $\mathrm{O}$ altă statistică oferită de către World Gastroenterology Global Guidelines (2014) ne arătă că disfagia afectează în proporție de $40-70 \%$ pacienții post Accident Vascular Cerebral, 6o-80\% din pacienții cu condiții meurogenerative, peste $13 \%$ pacienții cu vâstă de peste 65 de ani, 51\% din persoanele instituționalizate în centre de îngrijire permanentă, și $60-75 \%$ din pacienții ce au urmat proceduri de radioterapie post cancere de gât și cap (Ronkainen, J. și colab. 2007).

Etiologia diagnostică a disfagiei este una complexă și cuprinde foarte multe patologii, prin urmare și tratamentul acesteia depinde de cauza disfagiei, de simptomale asociate și timpul de probleme de deglutiție pe care pacientul le acuză. Managementulul disfagiei trebuie să se bazeze pe rezultatele evaluării clinice și să țină seamă de o serie de factori cu privire la starea generală de sătătate a pacientului, a prognosticului bolii, dar să includă și factori ce țin de starea și diagnosticul persoane, de nivelul intelectual al acesteia, de situația socială, de valorile culturale, satrea economică, motivația și alegerile personale.

30\%-65\% dintre persoanele care au suferit un accident vascular cerebral prezintă simptome disfagice, ce se ameliorează cu precădere în prima lună post AVC, însă la un procent reprezentativ de cazuri, aceste simptome putând persista și până la 6 luni (Norine, C. și colab., 2009). În etapa acută a AVC în proporție de 40-60\% dintre pacienți în urma simptomelor disfagice se confruntă cu malnutriție și scădere în greutate prin reducerea aportului nutritiv și hidric. Din cauza problemelor survenite în urma AVC-ului pacientul prezintă tulburări de conștiință, deficite motorii, paralizii ale structurilor implicate în deglutiție, agnozie, apraxie, etc toate cu impact direct asupra alimentației acestuia, stare care se prelungește pe perioada spitalizării prelungite, a recuperării, necesitând asistență îndelungată și costuri ridicate. De asemenea un risc marcant la această categorie de pacienți o reprezintă pneumonia de asipirație a cărei pondere este de aproximativ 35\% din decesele postAVC (Livia, S, și colab, 2012). Complicațiile ce apar în urma AVC-ului și a disfagiei au un impact negativ asupra bunăstării fizice, psihice și sociale a pacienților, asupra calității vieții 
pacienților, cât și asupra familiei și aparținătorilor acestora (Carnaby-Mann, G., Lenius, K., Crary, M., 2007).

Clasificarea internaţională a funcţionării, dizabilităţii şi sănătăţii (CIF, 2004) încadrează termenul de calitate a vieții într-o dimensiune bio-psiho-socială, punând accent pe limitările și capacitățile individului de a participa în diverse domenii existențiale. De aceea calitatea vieții este asociată frecvent cu o serie de constructe de satisfacție a vieții din domeniul social, fizic/motric, emoțional și cognitiv (McKevitt C, 2003), ea putând fi monitorizată constant pe parcursul procesului recuperator al deficitelor funcționale, cognitive și sociale ale pacientului.

În sondarea calității vieții persoanelor cu disfagie ca urmare a unui accident vascular trebuie analizate mai multe domenii, precum dorința de alimentație: durata alimentației; frecvența simptomelor; funcția socială; selecția alimentelor; comunicarea; frica; sănătatea mentală: nevoia de somn și oboseală (Ayres, A și colab., 2016).

\section{Obiective}

Obiectivele specifice ale aceste cercetări vizează:

- Traducerea și adaptarea chestionarelor de evaluare a calității vieții la persoanele cu accident vascular cerebral cu disfagie - Stroke Specific Quality of life Scale (SS-QOL) și Swallowing Quality of life questionaire (SWAL-QOL);

- Elaborarea și implementarea planului de managemet și de reabilitare a abilităților de deglutiție;
- Evaluarea impactului pe care îl are programul terapeutic asupra calității vieții persoanelor ce AVC;

- Analiza calitativă a datelor obținute în urma aplicării instrumentelor de evaluare prin analiza indicilor, a simptomatologiei persistente sau remise, a frecvenței simptomatologiei.

\section{Ipotezele cercetări}

Impotezele de la care s-a plecat sunt:

- Se vor înregistra diferențe semnificative în scăderea frecvenței simptomatologiei disfagiei ca urmare a parcurgerii programului terapeutic, generând o creștere semnificativă a calității vieții acestora.

- $\quad$ In ceea ce privește selecția dietei și consistenței alimentare se vor înregistra diferențe semnificative în urma parcurgerii terapiei deglutiționale;

- Un nivel semnificativ al deficienței înregistrate va fi un predictor al nivelului de percepție a calității vieții.

\section{Participanți}

La acest studiu au participat 6 subiecți ce au fost internați în cadrul Spitalului de Recuperarea Polaris Medical, fiind internați pe secția de neurologie ca urmare a unei patologii neurologice de tipul accidentului vascular cerebral ischemic sau hemoragic după caz. Înaintea începerii procedurilor de evaluare pacienții au fost informați despre această cercetare, oferindu-și acordul de participare la acesta. Media de vârstă la momentul internării paciențiilor a fost de cinzeci și șapte de ani și cinci luni, cel mai învârstă având șaizeci și nouă de ani și zece luni, iar cel mai tânăr participant având treizeci și nouă de ani și nouă luni. Având în vedere 
durata de timp de la accidentul vascular cerebral, durata medie a bolii a acestor pacienți a fost de două luni, cea mai recentă durată fiind de o lună, iar cea mai îndepărtată fiind de opt luni. Nivelul de educație a subiecțiilor surprinși în studiu au fost în proporție de 50\% aveau studii superioare, iar 50\% aveau studii medii. Dintre cei șase participanți la studiu patru au fost bărbați și două femei.

Tabel. I. Caracteristici ale participaților în

\begin{tabular}{|c|c|c|c|c|c|}
\hline & $\begin{array}{l}\text { Vârs } \\
\text { tă }\end{array}$ & $\begin{array}{l}\text { Gen } \\
\text { ul }\end{array}$ & Studii & $\begin{array}{l}\text { Dura } \\
\text { ta de } \\
\text { la } \\
\text { AVC }\end{array}$ & $\begin{array}{l}\text { Modul } \\
\text { de } \\
\text { hrănire }\end{array}$ \\
\hline C. & 54 și & $M$ & Medii & 1 & tub \\
\hline M & 61 & & & luna & $\begin{array}{l}\text { nazogast } \\
\text { ric }\end{array}$ \\
\hline I.V. & $\begin{array}{l}\text { 6o și } \\
21\end{array}$ & $\mathrm{~F}$ & Medii & $\begin{array}{l}4 \\
\text { luni }\end{array}$ & $\begin{array}{l}\text { oral- } \\
\text { consisten } \\
\text { ță } \\
\text { modificat } \\
\breve{a}\end{array}$ \\
\hline C.C & $\begin{array}{l}34 \text { și } \\
91\end{array}$ & M & $\begin{array}{l}\text { Superio } \\
\text { are }\end{array}$ & $\begin{array}{l}8 \\
\text { luni }\end{array}$ & $\begin{array}{l}\text { gastrosto } \\
\text { mă și } \\
\text { traheosto } \\
\text { mă }\end{array}$ \\
\hline $\begin{array}{l}\text { D. } \\
\text { O. }\end{array}$ & $\begin{array}{l}69 \text { și } \\
101\end{array}$ & M & $\begin{array}{l}\text { Superio } \\
\text { are }\end{array}$ & $\begin{array}{l}2 \\
\text { luni }\end{array}$ & $\begin{array}{l}\text { sondă } \\
\text { nazogast } \\
\text { rică }\end{array}$ \\
\hline $\begin{array}{l}\text { G. } \\
\text { R. }\end{array}$ & $\begin{array}{l}56 \text { și } \\
11\end{array}$ & $\mathrm{~F}$ & Medii & $\begin{array}{l}3 \\
\text { luni }\end{array}$ & $\begin{array}{l}\text { dificultăt } \\
\text { i lichide }\end{array}$ \\
\hline $\begin{array}{l}\text { P.E } \\
.\end{array}$ & $\begin{array}{l}67 \text { și } \\
31\end{array}$ & $\mathrm{M}$ & $\begin{array}{l}\text { Superio } \\
\text { are }\end{array}$ & $\begin{array}{l}4 \\
\text { luni }\end{array}$ & $\begin{array}{l}\text { dificultăt } \\
\text { i pastile, } \\
\text { lichide }\end{array}$ \\
\hline
\end{tabular}

Participanții la acest studiu au fost selectați în baza următoarelor criterii: 1) patologie survenită după accident vascular cerebral; 2) prezența tulburărilor de deglutiție, 3) durata de spitalizare de minim 4 săptămâni. De asemenea, au existat o serie de criterii de excludere din studiu care au ținut cont de: a) pacienții cu tulburări de limbaj receptiv și expresiv; b) pacienții cu deficiență de auz care întâmpinau dificultăți în înțelegerea programului de intervenție și c) pacienții cu demență. Informațiile au fost obținute în baza dosarului medical al pacientului, a discuțiilor din cadrul echipei multișciplinare și a interviului $\mathrm{cu}$ pacientul.

\section{Instrumente utilizate}

În cadrul acestei lucrări de cercetare au fost utilizate următoarele instrumente de evaluare și screening:

-Stroke Specific Quality of life Scale (SSQOL);

- Barthel Index; Swalloing Quality of Life Questionnaire (SWAL-QOL);

-Water swallow test; Modified Wather swallow test;

-Instrument de evaluare a deglutiției (IED-10);

-Instrument de evaluare clinică a deglutiției;

- Disphagia handicap Index (DHI);

-Fork Drip test;

-Fork Pressure Test and Spoon Pressure Test.

$\mathrm{O}$ parte din aceste teste au evaluat calitatea vieții ca urmare a accidentului vascular cerebral și a disfagiei, pe când o altă partea au evaluat gradul de afectare și dizabilitate a persoanei precum este indexul Barthel, iar restul au avut ca scop evaluarea statusului actual anatomic și funcțional al deglutiției, precum și metode standardizate de modificare a consistenței alimentare. Toate aceste instrumente de evaluare și diagnostic au fost aplicate în cadrul cercetării de două ori, la începutul și la finalul programului terapeutic. 


\section{Metodologie}

Cercetarea de față a fost realizat în cadrul Spitalului de Recuperare Polaris Medical. Pentru început după procedura de internare pacientul a fost informat de existența acestei cercetări și de posibilitatea participării la acesta. După acordul informat obținut de la fiecare pacient în parte, pacientul a fost evaluat și testat cu instrumetele pe care le-am menționat în subcapitolul anterior. Procedura de testarea s-a realizat pe de o parte în cabinetul logopedului sau în salonul fiecărui pacient după caz, procedura realizându-se pe parcursul primei ședințe de terapie ce a durat 50 de min, organizată sub forma unui interviu semistructurat. Logopedul a citit itemii și răspunsurile fiecărui instrument pentru fiecare pacient, pentru a minimiza efectul nivelului scăzut de educație sau a acuității vizuale scăzute, asigurându-se astfel o înțelegere corectă a chestionarelor, eliminând răspunsurile false datorate de lipsa înțelegerii a acestuia. Această procedură s-a realizat pentru toți pacienții. Colectarea datelor a avut loc din martie până în luna august 2019.

În baza rezultatelor surprinse prin intermediul testelor aplicate pentru fiecare pacient în parte s-a realizat un program de intervenție logopedică, ce a constat în 5 ședințe pe săptămână de 40 de minute pe o durată de 4 săptămâni. Numărul total de ședințe realizate cu fiecare pacient în parte au fost de 20 . Prima și ultima ședință a perioadei de cercetare au fost destinate pentru etapa de evaluare și aplicare a testelor și chestionarelor selectate. Cea de-a doua ședință de terapie a avut drept scop informarea pacientului despre programul terapeutic, modul în care va fi acesta aplicat și frecvența exercițiilor, informații despre selecția alimentelor, durata mesei, reguli și postura din timpul mesei, reguli de igienă orală etc. Ședințele 3-17 s-au concentrat cu precădere pe implementarea planului recuperator al disfagiei $\mathrm{cu}$ monitorizarea atentă a modificărilor ce survin și a reglării consitenței alimentare în raport cu fiecare stadiu recuperator.

\section{Panul terapeutic}

În baza informațiilor extrase în urma evaluării și a investigațiilor clinice, s-a întocmit fiecărui pacient în parte un program terapeutic personalizat ce a constat în trei faze: (a). Terapie indirectă (în cadrul acestei faze s-au realizat o serie de tehnici și exerciții specifice de antrenare a structurilor anatomice implicate în deglutiție), (b.) O fază ce a constat în aplicarea unor manevre compensatorii și tehnici directe de antrenare a înghițirii; iar cea de treia fază (c). a constat în terapia directă - prin administrarea alimentelor pe cale orală utilizându-se tehnici de modificare a consistenței alimentare.

Terapie indirectă s-a concentart de o serie de tehnici și exerciții specifice terapiei indirecte a disfagiei:

-Exerciții pentru antrenarea musculaturii gâtului:

-Exerciții pentru coordonarea și motricitatea buzelor - facilitează abilitatea pacientului de a menține lichidele și alimentele în cavitatea bucală;

-Exerciții pentru coordonarea și motricitatea obrajilor- ușurează rotația 
bolului alimentar în cadrul cavității bucale și menținerea acestuia.

- Exerciții pentru coordonarea și motricitatea mandibulei- facilitează ingerarea și mușcarea alimentelor, jucând un rol activ în procesul masticator. Mai mult îmbunătățește deschiderea sfincterului esofagian superior în timpul deglutiției, fiiind recomandat la pacienții cu dificultăți în ridicarea hioidului și /sau deschiderea inadecvata a sfincterului esofagian superior.

-Exerciții pentru coordonarea și motricitatea limbii- îmbunătățesc controlul limbii în manipularea și formarea bolului alimentar, a masticației și a propulsiei bolului spre faringe; creșterea masei musculare; creșterea presiunii înghițirii; diminuarea aspirației

-Exerciții pentru coordonarea și motricitatea vălului palatin îmbunătățește rididarea și sigilarea cavității nazale în timpul înghițirii:

-Exerciții pentru coordonarea și motricitatea faringelui:

-Exerciții pentru coordonarea și motricitatea laringelui;

-Exercițiul Shaker

Manevre compensatorii și tehnici directe de antrenare a înghițirii care au fost utilizat sunt:

-Aplecarea/flexia/înclinarea bărbiei în timpul înghițirii

- Rotația capului spre partea afectată

-Înclinarea capului spre partea sănătoasă

-Deglutiția supragolică

- Manevra Mendelsohn

-Înghițirea cu efort
- Tehnica Masako

- Tehnica Lee Silverman

\section{Studiu de caz}

\section{Date personale}

C.M. în vârstă de 54 de ani și 6 luni, a fost transferat în cadrul clinicii noastre în martie 2019 ca urmare a unui accident vascular cerebral ischemic pseudobulbar de $4 \mathrm{~mm}$, apărut în aprilie. Pacientul are asociat în istoricul medical hipertensiune arterială grad II, fără ateromatoză carotidiană, nefiind cunoscut cu alergii la diverse medicamente sau compuși chimici, nu prezintă traheostomizare. Pacientul prezintă sondă nazogastrică de aproximativ o lună de la accidentul vascular cerebral, ca urmare a unui episod de sufocare prin înnec cu lichide.

\section{Demersul evaluatĩv}

Evaluarea pacientului C.M. a debutat la data de 19.05.2019, o dată cu internarea acestuia pe secția de neurologie din cadrul clinicii noastre, atitudinea și comportamentul acestuia față de acest demers fiind unul receptiv și de cooperare cu echipa medicală. În baza interviului realizat cu C.M. și a aplicării instrumentelor de diagnostic acesta acuză imposibilitatea de a înghiți lichide, alimente solide, aceeași atitudine fiind prezentă și față de propriile secreții, pe care le elimină constant pe timpul celor 24 ore prin scuipare. Pacientul relatează un episod de înnec cu apă pe care l-a avut pe prioada internării în spitalul de unde a fost transferat, în urma căruia i s-a montat sonda nazogastrică. Simptomatologia acuzată de pacient la momentul evaluării ințiale a fost: imposibilitatea înghițirii de lichide, alimente solide și a propriilor secreții; teamă, anxietate și frică de a nu se 
înneca și a se sufoca, gură uscată, spută și secreții groase, cleioase pe care le elimina prin scuipare în permanență; senzație de înnec și nod în gât; frecvente episoade de sughiț; senzație dureroasă la nivelul gâtului ce a apărut ca urmare a procedurilor multiple (5 încercări) de introducere a sondei nazogastrice; pierdere în greutate; deprivare de somn și oboseală acută ca urmare a hipervigilenței din timpul nopții și a eliminării constante a secrețiilor. Având în vedere diagnosticul specific al pacientului, acesta nu prezenta deficite de natură motorie a membrelor superioare sau inferioare, funcțiile de autoîngrijire de fiind deloc afectată în urma accidentului vascular cerebral, abilitățile de comunicare erau funcționale atât din punct de vedere receptiv cât și expresiv.
În baza evaluării obiective clinice s-a constat: C.M este un pacient cooperant și implicat în demersul evaluativ, orientat temporo-spațial, prezintă disfagie pentru solide și lichide ca urmare a unui accident vascular cerebral în teritoriul pseudobulbar de $4 \mathrm{~mm}$. Ca metodă de hrănire utilizează independent o metodă alternativă de nutriție și anume tub nasogastric de aproximativ 4 săptămâni.

Pe parcursul primei întâlniri pacientului i s-a aplicat instrumentul de evaluare clinică a deglutiției, Wather test și Modified wather test ce au avut ca scop examinarea structurilor anatomice implicate în deglutiție, motricitatea și coordonarea acestor structuri, precum și screeningul deglutiției. În tabelul de mai jos sunt prezentate toate datele pe care leam obținut în urma procesului evaluativ inițial.

\section{Tabel II. Rezultate obținute în urma aplicării}

\section{Instrument de evaluare clinică a deglutiției \\ Modified Wather swallow test; respectiv Water swallow test}

Dentiție dentiție completă, cu o igienă bună fară resturi alimentare, carii, sau absența dinților

Buze $\quad$ tipic conformate, în starea de repaus nu se indentifică asimetrii, edeme, eriteme sau leziuni, prezintă o bună mobilitate și motricitate, tonus și forță musculară bună, sunt prezente mișcări de protruzie, retragere și rotație a buzelor, fără a fi prezente mișcări involuntare, spasme, tremus etc

\begin{tabular}{ll}
\hline Limbă & în stare de repaus prezintă o conformație normală, simetrică fără edeme, eriteme sau \\
& leziuni; prezintă un tonus musculat bun în timpul stării de proeminență retragere și \\
& lateralizare, mișcările sunt constante, succesive, controlate, fără mișcări parazite, tremur, \\
& spasme sau diskinezii; realizează mișcări de coborâre/ridicare, lateralizare, rotație fără \\
& modificări clinice;
\end{tabular}

Maxilar maxilar normal configurat, mobil, ce realizează mișcări de deschidere/închidere, lateralizare, proeminență, retragere fără mișcări involuntare sau necontrolate precum tremur, spasm, semiocluzie

\footnotetext{
Palatul normal configurat fără edeme, eriteme, leziuni, ușor coborât spre dreapta ca urmare a moale $\quad$ sondei nazogastrice, simetric, cu o senzație ușor întârziată de gag, mișcarea de ridicare a valului prezentă și susținerea acestuia ușor modificată; fără modificări în mișcările alternative de ridicare/relaxare.
} 


\begin{tabular}{|c|c|}
\hline Respirație & $\begin{array}{l}\text { respirație normală, diferențiază respirația orală de cea nazală, undă respiratorie pe inspir } \\
\text { profundă, lungă, susținută; volum respirator tipic, TMF (timpul maxim de fonație } 15 \text { sec.) }\end{array}$ \\
\hline Voce & $\begin{array}{l}\text { normală, vibrantă, sonoră, gravă, cu volum normal și intensitate vocală optimă, testul s/z } \\
\text { negativ clinic. }\end{array}$ \\
\hline Deglutiție & $\begin{array}{l}\text { C.M. prezintă o disfagie moderată orofaringiană pentru solide și lichide cu o încărcătură } \\
\text { somatică de tipul axiogenă crescută. Prezintă un grad de vigilență și atenție crescut, fără } \\
\text { pneumonii în antecedentele medicale. În urma administrării protocolului de testare } \\
\text { prezintă în cazul consistenței apei tuse spontană și voluntară puternică, cu senzație de } \\
\text { înnec, senzație de rest lichid la nivelul gâtului; curăță voluntar gâtul prin raclaje } \\
\text { consecutive puternice; în cazul modificării consistenței alimentare pacientul prezintă o } \\
\text { ușoară ameliorare pentru consistența nectarului, însă în cazul consistențelor mai groase } \\
\text { precum budincă simptomatologia persistă cu dificultate crescută în înghițire. De } \\
\text { asemenea, se observă o creștere a oboselii pe parcursul administrarii orale, cu modificări } \\
\text { ușoare ale vocii, voce umedă. }\end{array}$ \\
\hline
\end{tabular}

A doua etapă a evaluării a constat în aplicarea testelor ce se bazau pe evaluare subiectivă a pacientului și făceau referire la simptomatologia problemelor de deglutiție, dar și aspecte ce țin de calitatea vieții.

\section{Rezultate obținute în urma evaluării subiective}

\section{Interpretare cantitativă}

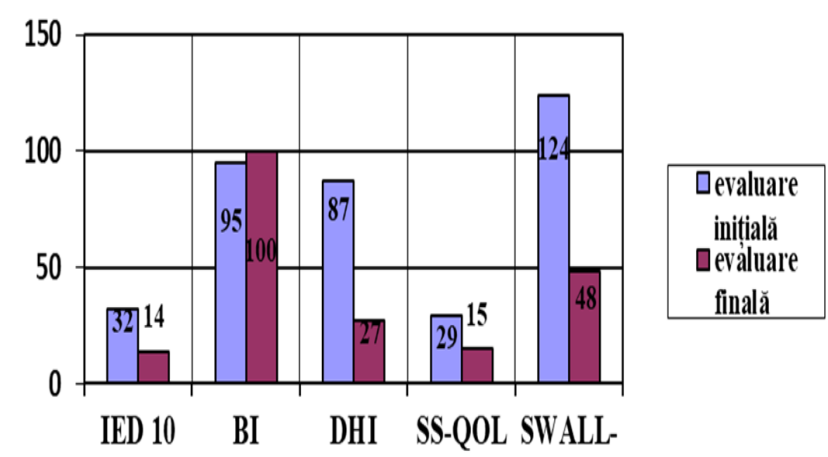

QOL

Figura 1. Grafic comparativ a scorurilor inițiale și finale ale lui C.M

\section{Interpretarea calitativă}

În urma aplicării instrumentului de evaluare a disfagiei (IED-10), C.M. a obținut la evaluarea inițială un scor de 32 , pe când în cadrul evaluării finale scorul său a scăzut la 14, fapt ce indică o evoluție favorabilă în reabilitatea disfagiei. Un astfel de scor indică faptul că C.M se confruntă $\mathrm{cu}$ o disfagie moderată ce îi afectează semnificativ viața, hrănirea realizându-se prin sondă nazogastrică. Itemii ce au indicat răspunsuri maxime au fost "Datorită problemei de deglutiție nu mănânc în locuri publice", "Înghițitul de lichide presupune efort suplimentar", "Înghițitul de solide presupune efort suplimentar", "Înghițitul pastilelor presupune un efort suplimentar.", "Actul înghițirii îmi provoacă stres", pe când itemul "Datorită problemei de deglutiție îmi este afectată pofta de mâncare" are un răspuns minim. Diferența dintre evaluarea inițială și cea finală indică o scădere mai mare de $50 \%$ a simptomatologiei acuzate de către pacient, acesta la externare hrănindu-se numai oral, sonda nazogastrică fiindu-i scoasă după 3 săptămâni de la începerea programului de recuperare. În ceea ce privește scorul obținut de C.M la Indexul Bartel putem afirma faptul că la evaluarea inițială acesta 
a înregistrat un scor de 95, iar la cea finală un scor de 100, ceea ce indică de fapt că nivelul de funcționare a lui C.M este unul foarte bun, iar impactul specific al accidentului vascular cerebral în zona pseudobulbară generează dificultăți stric la nivelul musculaturii faringelui $\mathrm{cu}$ implicare directă în deglutiție. Acest scor indică cu precădere dificultăți doar în domeniul hrănirii, C.M. hrănindu-se singur prin sonda nazogastrică. În cazul Indexului de Handicap pentru Disfagie, C.M a obținut un scor de 87 în cadrul evaluării inițiale, scor ce s-a modificat după parcurgerea planului de tratament la 28. Scorul crescut obținut de către C.M. indică o serioasă dificultate în înghițire. Scăderea semnificativă a acestui scor se explică pe fondul ameliorării înghițirii, C.M înlocuid hrănirea prin mijloace alternative cu o dietă orală ce constă în modificarea consistenței alimentare. În ceea ce privesc scorurile obținute la scalele care surprind componenta de calitate a vieții lui C.M. i s-au aplicat două chestionare SS-QOL și SWALL-QOL. În cazul primului chestionar, SS-QOL, ce evaluează impactul accidentului vascular asupra calității vieții, C.M. a obținut la evaluarea inițială un scor de 33 , ceea ce confirmă faptul că impactul accidentului vascular suferit de C.M. nu a fost unul major, ce nu a avut implicații negative asupra intregrității fizice, a mobilității și funcționării motorii și a autonomiei personale, a funcționării degetelor de la mâini, etc. $\mathrm{Cu}$ toate că impactul accidentului vascular cerebral suferit de C.M a fost unul ce a determinat probleme specifice de natură deglutițională, la evaluarea finală s-a observat o scădere a scorului inițial la 17 , ceea ce indică faptul că totuși C.M a prezentat îmbunătățiri la subscalele energie, roluri familiale și asupra dispoziției sale față de condiția sa.

Cel de-al doilea instrument ce a evaluat calitatea vieții la persoanele cu disfagie a fost SWALL-QOL, unde C.M. în faza inițială a testării a înregistrat un scor de 124, ceea ce indică că participantul la studiu prezintă probleme semnificative de înghițire ce îi afectează viața într-un mod marcant. Cele mai importante domenii ce au înregistrat scoruri crescute au fost cele legate de durata alimentației, frecvența simptomelor, frica și conținutul emoțional, somnul și oboseala. La evaluarea finală C.M. a obținut la chestionarul SWALL-QOL un scor de 48 , ceea ce indică succesul demersului terapeutic asupra simptomatologiei și a evoluției pozitive a cazului. Astfel la domeniile la care inițial C.M a obținut scoruri maxime, la evaluarea finală acestea s-au diminuat semnificativ, ceea ce indică o creștere a calității vieții și o apropiere cât mai mare de viața anterioară a acestuia.

Concluzii generale

Rezultatele obținute prin aplicarea Instrumentului de evaluare a deglutiției (IED-10) a relevat faptul că, patru din cei șase participanți prezentau disfagie moderată spre severă, pe când doi dintre aceștia prezentau doar forme ușoare de disfagie, un caz pentru lichide, iar celălalt pentru înghițirea pastilelor. Având în vedere evoluția datele pe care pacienții leau înregistrat la finalul perioadei de cercetare ca urmare a parcurgerii programului de recuperare pentru disfagie, putem afirma faptul că impactul terapiei logopedice a avut un efect pozitiv asupra ameliorării simptomatologiei inghițirii, pacienții reușind să se alimeteze mult mai ușor, mai corect și cu un risc de 
aspirație mai mic. Dintre cei șase participanți la doi dintre aceștia li s-au diminuat în totalitate simptomele, ei alimentându-se și hidratându-se normal, doi prezintă simptomatologie ușoară în curs de remisie, iar pe când ceilalții doi prezintă o dietă pasierată de consistența piureului, alimentelor moi și semitari.

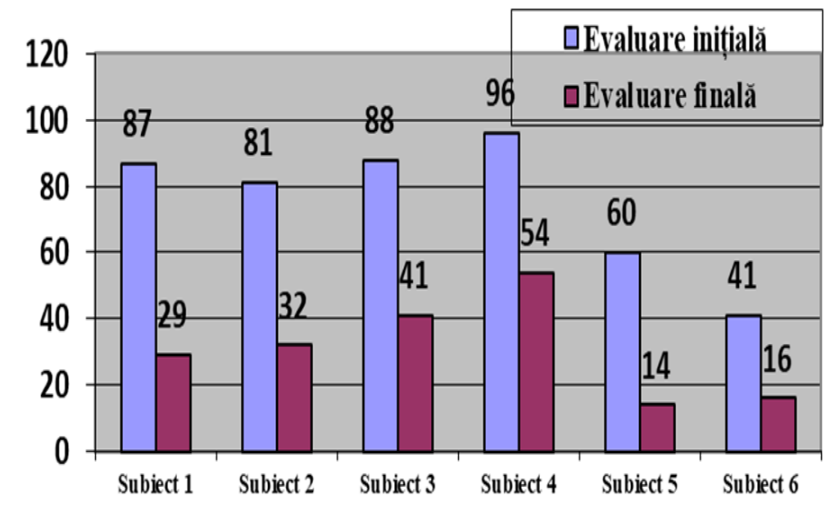

Figura 2. Scorurile obținute de subiecți la Instrumentul de evaluare a disfagiei (IED-10)

Prin analiza scorurilor obținute de pacienți la instrumentele Deglutition Handicap Index și Swalloing Quality of life test s-a putut observa faptul că cu cât scorurile sunt mai mari cu atât impactul asupra calității vieții va fi unul mai semnificativ. $\mathrm{Cu}$ alte cuvinte dacă pacientul prezintă deficite severe ale înghițirii asociate $\mathrm{cu}$ o serie de metode alternative de alimentare precum sunt sonda gastrică, sonda nazogastrică, hrănirea parienterală, cu asociere de traheostomizare cu atât perioada de recuperare va fi mai lungă, iar progresele recuperatorii mai lente cu pondere mai redusă de recuperare. Prin urmare este foarte important în aceste cazuri să ținem seamă de gravitatea efectelor accidentetului vascular survenit asupra pacientului și dacă acestea rămân izolate doar la nivelul deglutiției sau se asociază și cu alte dificultăți motorii. Pacienții a cărui diagnostic a fost exclusiv în zona trunchiului cerebral și nu au prezentat și alte deficite de natură motorie au înregistrat îmbunătățiri semnificative clinic, calitatea vieții findu-le influențată într-un mod pozitiv. În schimb în cazul pacienților care au prezentat accidente vasculare profunde $\mathrm{cu}$ traheosomizare progresul recuperator a fost unul ușor mai săzut, însă care a generat o scădere a scorului la instrumentul de evaluare a calității vieții, indicâd astfel o calitate a vieții crescută.

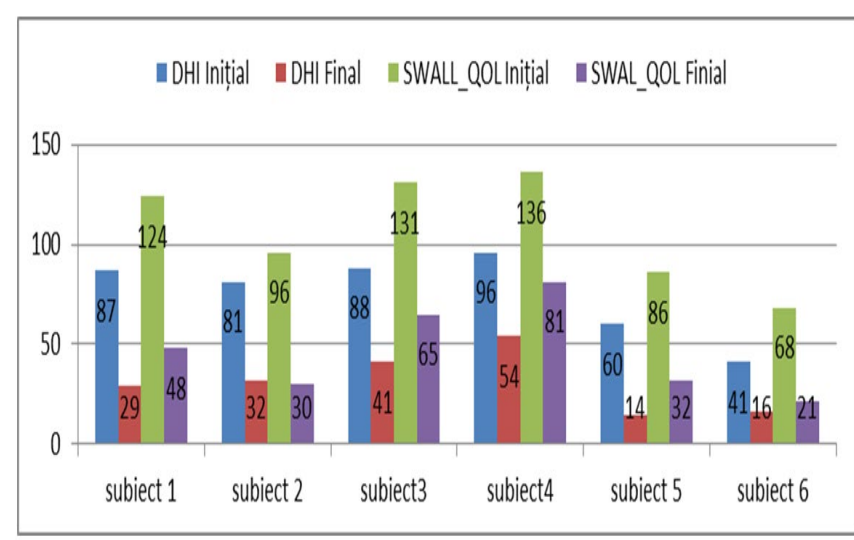

Figura 3. Scorurile obținute de subiecți la DHI și SWALL-QOL

În ceea ce privește corelația dintre scorurile obținute de subiecți la Indexul Barthel (BI) și scorurile obținute de aceștia la chestionarul Stroke Specific Quality of life (SS-QOL) putem afirma faptul că există o corelație invers proporțională dintre acestea. Adică un scor crescut la BI va indica un grad înalt de funcționare și mobilitate a pacientului, ceea ce va determina un scor scăzut la SS-QOL. Dintre cei șase pacienți incluși în cadrul acestui studiu doar un singur subiect prezintă un nivel de mobilitate și independență crescut, impactul accidentului vascular pe care l-a suferit 
fiind în zona pseudobulbară, generându-i doar deficite în hrănire. În schimb în cazul celorlalți cinci subiecți efectele patologiei suferite au indicat un impact negativ crescut asupra mobilității, funcționalității și independenței aceștora, prin urmare scorurile la SS-QOL sunt mult mai crescute ceea ce indică o calitate a vieții mai scăzută. Aceste scoruri se asociază deseori în rândul pacienților $\mathrm{cu}$ instabilitate emoțională, episoade de plâns facil, inhibiție emoțională scăzută, stări depresive ducând deseori la izolare socială, refuz de cooperare terapeutică, pusee de agresivitate și impulsivitate.

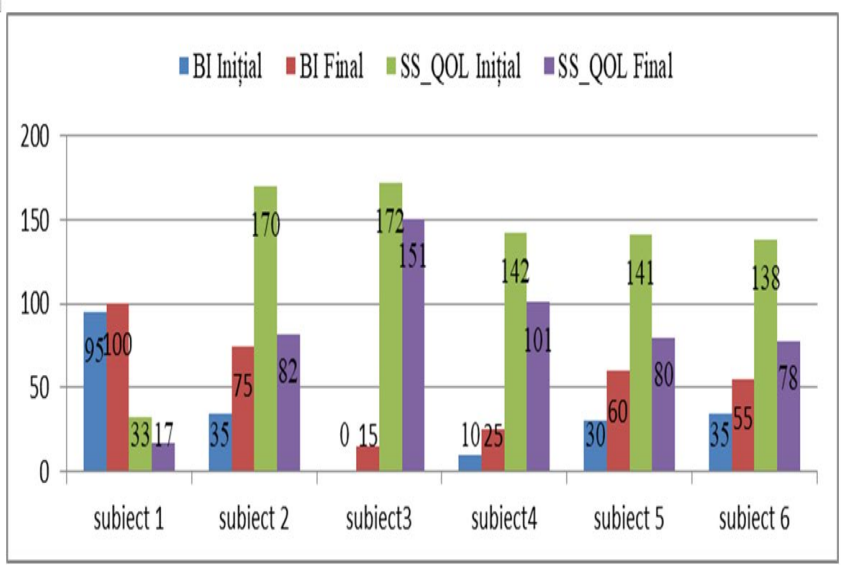

Figura 4. Scorurile obținute de subiecți la BI și SS-QOL

Totuși efectele terapiei disfagiei asupra calității vieții personaleor cu patologie neurologică prezintă un efect pozitiv asupra acestora, diminuând semnificativ riscul de manutriție, dezhidratare și complicații pulmonare grave ca urmare a pneumoniei de aspirație. Această concluzie vin în sprijinul ipotezelor noastre de cercetare, subliniind impactul benefic asupra creșterii independeinței fizice a persoanei de a se hrăni și hidrata, de a se reintegra social și de a participa la viața cotidiană a familiei.
De asemenea este necesar să prezentăm și limitele acestei cercetări. Una dintre aceste limite ar fi faptul că pentru a putea observa $\mathrm{cu}$ o mai mare certitudine impactul terapiei logopedice asupra calității vieții la persoanele cu patologii neurologice, este necesar un eșantion semnificativ pentru populația româniei, și un număr mai mare din punct de vedere numeric. De asemenea este imperios necesar utilizare formelor de evaluare clinică obiectiv. O altă limită pe care am identificat-o a fost topografia variată a patologiei pacienților ce au prezentat disfagie și diferența dintre duratele de suferință la care s-a intervenit. În cazul unor pacienți intervenindu-se terapeutic după o lună de la accidentul vascular cerebral, la alții după patru sau opt luni de la patologia survenită.

\section{Bibliografie}

Ayres, A., Jotz, G.P., Mello Rieder, C.R., Schumacher Schuh, A.F.și Olchik, M.R. (2016). The Impact of Dysphagia Therapy on Quality of Life in Patients with Parkinson's Disease as Measured by the Swallowing Quality of Life Questionnaire (SWALQOL) Int Arch Otorhinolaryngol, 20(3): 202-206

Bhattacharyya, N. (2014). The Prevalence of Dysphagia Among Adults in the United States, Otolaryngol Head Neck Surgicail, 151(5):765-769

Cabré, M., Serra-Prat, M., Force,L., Almirall, J., Palomera, E., Clavé, L. (2014). Oropharyngeal Dysphagia Is a Risk Factor for Readmission for Pneumonia in the Very Elderly Persons: Observational Prospective Study. Journal Gerontology A 
Biological Science Medical Science, 69(3):330-7

Carnaby-Mann, G., Lenius, K., Crary, M. (2007). Update on Assessment and Management of Dysphagia Post Stroke. Northeast Florida Medicine, 58(2):31-34

Jones B, (2003). Normal and Abnormal Swallowing. Imaging in Diagnosis and Therapy New York, ed. SpringerVerlag

Livia, S., Madhavan, A., Carnaby, G., Crary, M.A. (2012). Dysphagia in the Elderly: Management and Nutritional Considerations. Clinical In Intervention Anging, 7:287-298

McKevitt, C., Redfern, J., La-Placa,V., Wolfe, C.D.A. (2003). Defining and Using Quality of Life: A Survey of Health Care Professionals. Clinical rehabilitation, $17(8): 865-70$

Norine, C., Martin, R.E., Salter, K.L., Teasell, R., T.(2009). A Review of the Relationship Between Dysphagia and Malnutrition Following Stroke Journal of rehabilitation Medicine 41(9):707713

Ronkainen, J., Talley, N.J., Aro, P.T, Storskrubb, T., Johansson, S.T., Lind, T., Bolling-Sternevald, E., Vieth, E., Stolte, M., Walker, M., Agréus, L. (2007). Prevalence of Oesophageal Eosinophils and Eosinophilic Oesophagitis in Adults: The Population-Based Kalixanda Study. Gut, 56(5):615-620

https://apps.who.int/iris/bitstream/handl e/10665/42407/9241545429 rum.pdf;js essionid $=383 \mathrm{EFEoF} 292 \mathrm{Do} 4 \mathrm{~B} 84541 \mathrm{EAD}$ $5 \mathrm{~A}_{5} 6 \mathrm{DC}_{2} \mathrm{C}_{3}$ ? sequence $=5$

https://iddsi.org/Testing-Methods https://www.worldgastroenterology.org/ UserFiles/file/guidelines/dysphagiaenglish-2014.pdf

1. Profesor: Școala Gimnazială Specială-CRDEII, ClujNapoca.

Email: popa.ralucamariana@yahoo.com 